\title{
Evaluation of Household Knowledge on Water Supply, Hygiene and Sanitation Practices in So-Ava District (South Benin)
}

\begin{abstract}
Oswald F. Dan
Laboratory of Hydraulics and Water Control, National Institute of Water, University of Abomey-Calavi, Benin

Laboratory of Analysis and Research, Religions, Space and Development, University of Abomey-Calavi, Benin

\section{Mathieu Maurice Ahouansou \\ Luc O. Sintondji}

Laboratory of Hydraulics and Water Control, National Institute of Water, University of Abomey-Calavi, Benin

\section{Elliott R. Dossou-Yovo}

Laboratory of Hydraulics and Water Control, National Institute of Water,

University of Abomey-Calavi, Benin

Africa Rice Center, Bouaké, Côte d'Ivoire

Dodji Amouzouvi

Laboratory of Analysis and Research, Religions, Space and Development, University of Abomey-Calavi, Benin
\end{abstract}

Doi:10.19044/esj.2018.v14n26p173 URL:http://dx.doi.org/10.19044/esj.2018.v14n26p173

\begin{abstract}
The adoption of good practices in access to water, hygiene and sanitation is very important for the well-being and socio-economic development of any community. The objective of the study was to evaluate the knowledge and practices that households adopt regarding water supply, hygiene and sanitation. For this, a survey was conducted among 386 households in the seven districts of the commune of Sô-Ava. The data collected was analyzed using the XLSTAT 17 software and the Excel Spreadsheet. The results obtained show that in the commune of Sô-Ava, drilling is the most used water source and that nearly $66.33 \%$ of households do not cover their containers during the transport of water with a rate that varies from 2.85 to $25.39 \%$ from one borough to another. Sô-Ava is the district that has the highest number of latrines is that with a rate of $3.11 \%$. In addition, most households dispose of their garbage and wastewater either in the wild or in the water body in the absence of a waste collection system. The low level
\end{abstract}


of hygiene and sanitation observed could affect the quality of drinking water and hence the health of the population.

Keywords: Benin, Drinking water, Household, Hygiene, sanitation

\section{Introduction}

Access to clean water and improving sanitation is one of the major challenges of the $21^{\text {st }}$ Century (ACF, 2006). Water supply is a basic need and admitted as a fundamental right at the international level (Degbey et al., 2010). Despite the various efforts of the international community, more than 700 million people all over the world do not have access to a good quality of water, half of them lives in sub-Saharan Africa (WHO / UNICEF, 2014). Good water supply can contribute to good hygiene and basic sanitation (Hunter et al., 2010).

In Benin, access to water and basic sanitation is a fundamental problem in both urban and rural areas. According to the demographic survey of health conducted in 2006 in Benin, $40 \%$ of urban populations do not have access to toilets, with more than $80 \%$ in rural areas; more than $65 \%$ of wastewater is dumped in urban and rural areas and $92 \%$ of household waste is evacuated directly into the environment (INSAE, 2006). These poor hygiene and sanitation conditions have negative impacts on the health of the population that has become particularly vulnerable (children, women, disabled people, etc.) due to high epidemiological risks.

In Benin, the problem of accessibility to good quality of water still arises in rural and peri-urban areas. In the lacustrine municipality of Sô-Ava, rainwater, lake, boreholes and water from the National Water Society of Benin (SONEB) represent the different sources of water supply for the population. Safe drinking water coverage rate in the municipality of Sô-Ava is only 49.43 $\%$ (Municipality of Sô-Ava, 2014). Therefore, more than half of the inhabitants are exposed to water-related constraints including the consumption of unclean water, recurrent water shortages and long distance course for access to water, etc. However, drinking of contaminated and unhealthy water is a powerful factor in the transmission of waterborne diseases (Ahoyo et al., 2011). Thus, the consumption of dirty water can lead to the expression of waterborne diseases such as cholera, diarrhea, typhoid fever, gastrointestinal infections, etc. (Besancenot et al., 2004). The risks associated with the contamination of drinking water are various and may depend not only on the lack or inadequacy of hygiene measures at the source of supply but also on the means of transport, storage and consumption of water at home. Therefore, in order to identify the causes of water-related diseases, this study focuses on the assessment of the practices used by households in the supply chain of drinking water within the seven districts of the municipality of Sô-Ava. 


\section{Materials and methods}

\section{Study area}

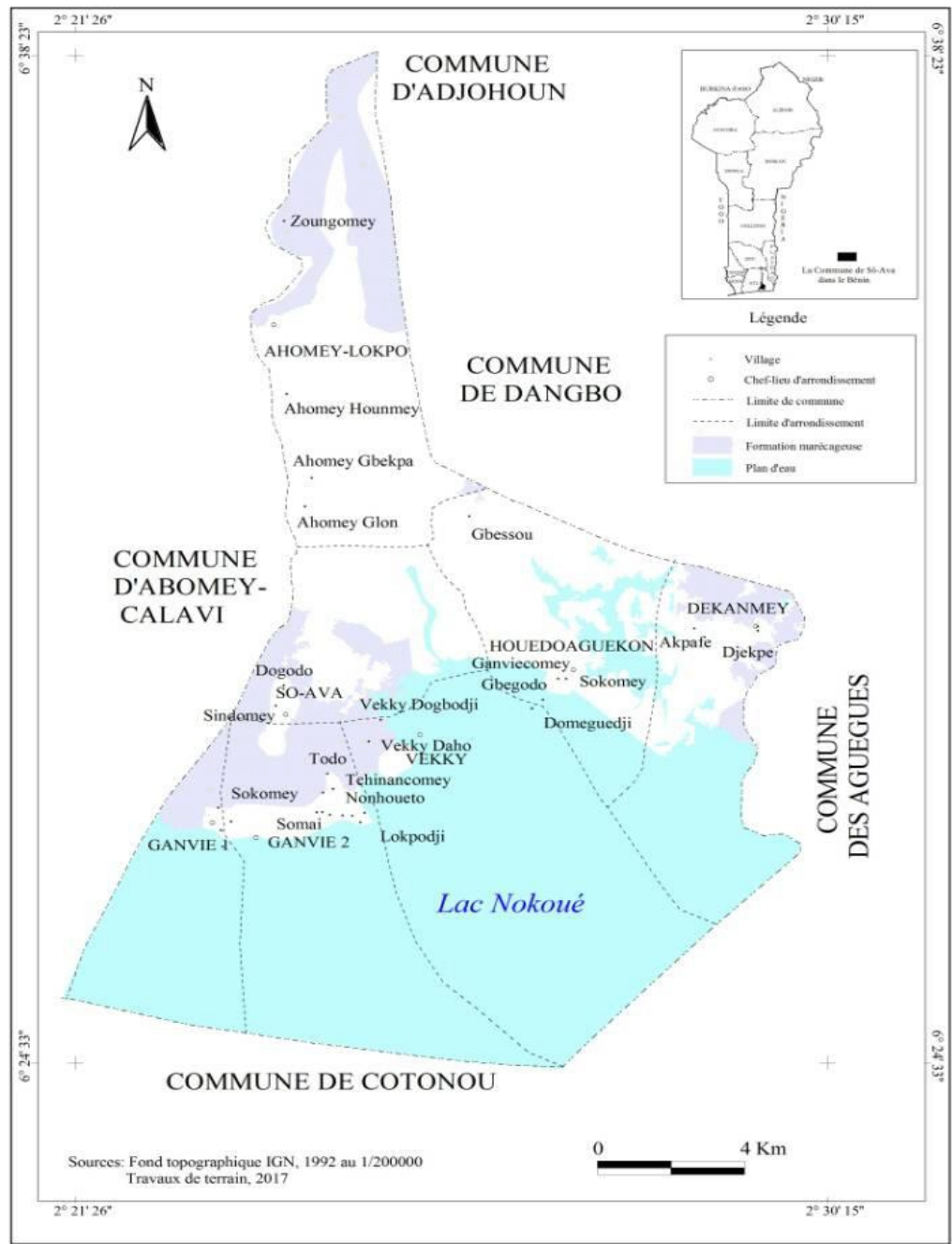

Figure 1 : Administrative organization of the municipality of Sô-Ava

The study was conducted in the lacustrine community of Sô-Ava, located in the Atlantic Department. The municipality of Sô-Ava is occupied by the lower valley of the Ouémé River and the Sô River from which it owes its name (Figure 1). With an area of $218 \mathrm{~km}^{2}$ (INSAE, 2002), it has 118.547 inhabitants with a density of about 567 inhabitants at $\mathrm{km}^{2}$ (INSAE, 2013).

Administratively, the municipality of Sô-Ava is divided into seven (07) districts namely: Sô-Ava, Vekky, Houédo-Aguékon, Dékanmè, Ganvié1, Ganvié2 and Ahomey-Lokpo (Municipality of Sô-Ava, 2014). 


\section{Sampling}

Random sampling was used in this study (Fortin, 2008).

The sample size (n) was determined using the formula of (Dagnélie, 1998):

$$
n=\frac{U_{1-\alpha / 2}^{2} \times p(1-p)}{d^{2}}
$$

- $\mathrm{n}=$ sample Size

- $\mathrm{U}^{2} 1-\alpha / 2=3.8416$ = value corresponding to a confidence rate of $95 \%$

- $\mathrm{p}=$ Proportion of households with access to a source of drinking water at Sô-ava $=49.43 \%$ (according to PCEauSô-Ava, 2014)

- $\mathrm{d}=$ desired accuracy $=5 \%$

386 households were sampled during this investigation, proportionately distributed within the seven (07) districts of the municipality of Sô-Ava. Three criteria were used to select the respondents : (a) be a permanent resident of SôAva Municipality, (b) own a source of water or at least have access to water, (c) give an agreement to be part of the investigation

The distribution of sampled households in each borough is presented by sex, ethnicity and level of education in table 1 .

Table 1 : characteristics of selected households in each borough

\begin{tabular}{|c|c|c|c|c|c|c|c|c|}
\hline \multirow[b]{2}{*}{ District } & \multicolumn{2}{|c|}{ Sex } & \multicolumn{2}{|c|}{ Ethnic } & \multicolumn{4}{|c|}{ Education Level } \\
\hline & Female & Male & Toffin & Other & Any & Primary & Secondary & University \\
\hline Ahomey-Lokpo & 19 & 7 & 25 & 1 & 23 & 3 & 0 & 0 \\
\hline Dékanmey & 21 & 4 & 24 & 1 & 22 & 2 & 1 & 0 \\
\hline Ganvié I & 40 & 14 & 53 & 1 & 45 & 6 & 2 & 1 \\
\hline Ganvié II & 38 & 14 & 50 & 2 & 40 & 2 & 8 & 2 \\
\hline Houédo-Aguékon & 51 & 9 & 57 & 3 & 48 & 8 & 4 & 0 \\
\hline Sô-Ava & 48 & 6 & 49 & 5 & 42 & 5 & 6 & 1 \\
\hline Vêkky & 96 & 19 & 113 & 2 & 95 & 12 & 8 & 0 \\
\hline Total & 313 & 73 & 371 & 15 & 315 & 38 & 29 & 4 \\
\hline
\end{tabular}

Statistical Analyses: The data were analyzed using the XLSTAT 17 software. After calculating the frequencies, the different analyses were performed and then compared using the chi-square test with a threshold of significance set at 0.05 .

\section{Results and discussion}

\subsection{Socio-demographic characteristics of the respondents}

The socio-demographic survey focused on 386 households distributed proportionately in the seven (07) districts of the municipality of Sô-Ava. The analysis of the results showed that the percentage of men surveyed varied between 1.04 and $4.92 \%$ while that of women was between 4.92 and $24.87 \%$. 
The interviewees were mostly made up of women because they were the ones who traditionally have the responsibility to provide the water supply in the household. The study found that there was no significant link between the sex and the district.

The socio-cultural group of the "Toffin" was dominant within all the districts with a frequency varying from 6.22 to $29.27 \%$. These statistics are in line with those contained in the Municipal Development Plan (Municipality of Sô-Ava, 2015) which indicates the "Toffin" as the majority ethnic group. The results of the analysis showed that there was no significant statistical difference between the socio-cultural group and the district.

In terms of school attendance at the district level, respondents with no level of education ranged from 5.70 to $24.61 \%$, while the percentage of those with primary education was between 0.52 and $3.11 \%$. For those who have attended high school and university, the attendance rate does not exceed 2.07 and $0.52 \%$ respectively. We found that the frequency decreases as the level of education increases. The level of education was very low in all the districts, particularly at those of Ahomey-lokpo and Dékanmey, where at least seven interviewees have to be covered to hope to find one who has done at least the primary school. The statistical results show that the level of instruction was not bound to the district.

The analysis of the various indicators revealed that trade was the main activity that most interviewees carried out in all the districts with a rate that fluctuates between 4.15 and $22.28 \%$ while fishing practice does not exceed $3.11 \%$. There are also other professions such as: civil servants, health workers, teachers, students, housewives and crafts (sewing, hairdressing, painting, etc.) whose frequency varied from 0.78 to $4.40 \%$ according to the district. However, it should be recalled that the trade sector was dominated by uneducated women and girls who carried out different kinds of activities (Municipality of Sô-Ava, 2015). Our findings showed that the professional activity was statistically related to the respondents district.

The average size of households interviewed in the seven districts was generally between four (04) and seven (07) individuals with a frequency of 2.59 and $14.51 \%$. The statistical tests did not show a significant difference between the districts and the size of the households.

\subsection{Determinants of water hygiene}

\subsubsection{Supply of households in drinking water}

- Water sources used by households

Table 2 shows the types of water consumed by households in the municipality of Sô-Ava. These are water from the National Society of Water in Benin (SONEB), drilling, surface water (lake) and then rainwater. Drilling water was the most frequently water source used in all the districts both in dry 
and rainy seasons. Although Sô-Ava is the only district to dispose of the branches of the SONEB, drilling water was the most consumed by the population. Statistical results have been shown that there is a significant link between the district and the Water source.

Table 2 : Source of water used by households in the districts of the Municipality of Sô-Ava in dry (pvalue $\left.<\mathbf{0 . 0 0 0 1} ; \mathbf{C h i}^{2}=\mathbf{1 5 7 . 3 4}\right)$ and rainy seasons $\left(\mathrm{p}\right.$-value $\left.<\mathbf{0 . 0 0 0 1}, \mathrm{Chi}^{2}=\mathbf{1 9 5 . 3 7}\right)$

\begin{tabular}{|c|c|c|c|}
\hline \multirow[t]{2}{*}{ District } & \multirow[t]{2}{*}{ Indicator } & \multicolumn{2}{|c|}{$\begin{array}{l}\text { Percentage of drinking water } \\
\text { sources used by households }\end{array}$} \\
\hline & & Dry & Rainy \\
\hline \multicolumn{2}{|c|}{ P-value } & $<0.0001$ & $<0.0001$ \\
\hline \multirow[t]{4}{*}{ Ahomey-Lokpo } & SONEB & 0 & 0.26 \\
\hline & Drilling & 6.74 & 4.4 \\
\hline & Surface Water & 0 & 0 \\
\hline & Rain & 0 & 2.07 \\
\hline \multirow[t]{4}{*}{ Dékanmey } & SONEB & 0 & 0 \\
\hline & Drilling & 6.48 & 4.4 \\
\hline & Surface Water & 0 & 0.52 \\
\hline & Rain & 0 & 1.55 \\
\hline \multirow[t]{4}{*}{ Ganvié I } & SONEB & 0 & 0 \\
\hline & Drilling & 13.99 & 13.47 \\
\hline & Surface Water & 0 & 0 \\
\hline & Rain & 0 & 0.52 \\
\hline \multirow[t]{4}{*}{ Ganvié II } & SONEB & 0 & 0 \\
\hline & Drilling & 13.47 & 12.95 \\
\hline & Surface Water & 0 & 0 \\
\hline & Rain & 0 & 0.52 \\
\hline \multirow[t]{4}{*}{ Houédo-Aguékon } & SONEB & 0 & 0 \\
\hline & Drilling & 15.54 & 13.47 \\
\hline & Surface Water & 0 & 0 \\
\hline & Rain & & 2.07 \\
\hline \multirow[t]{4}{*}{ Sô-Ava } & SONEB & 5.96 & 5.96 \\
\hline & Drilling & 7.77 & 7.51 \\
\hline & Surface Water & 0.26 & 0 \\
\hline & Rain & 0 & 0.52 \\
\hline \multirow[t]{4}{*}{ Vêkky } & SONEB & 0 & 0.26 \\
\hline & Drilling & 29.79 & 27.98 \\
\hline & Surface Water & 0 & 0 \\
\hline & Rain & 0 & 1.55 \\
\hline \multicolumn{2}{|c|}{ Total } & 100 & 100 \\
\hline
\end{tabular}


- Difficulties in supplying drinking water

The analysis in Table $\mathbf{3}$ showed the various difficulties experienced by households in drinking water supply at the district level. The long queue was the main difficulty mentioned by households in all districts except for Sô-Ava where the cost of water was expensive which was the major problem. Other constraints such as: the distance between the dwelling and the water point, the repeated cuts, the high cost of water, etc. though specific to each borough, frequently were mentioned by the respondents. The statistical results indicated the existence of a link between the difficulties related to the supply of drinking water and the districts.

Table 3 : Difficulties associated with drinking water supply within each borough (p-value <

\begin{tabular}{|c|c|c|}
\hline District & Indicator & $\begin{array}{l}\text { Percentage of difficulties } \\
\text { related to drinking water } \\
\text { supply }\end{array}$ \\
\hline \multicolumn{2}{|c|}{ P-value } & $<0.0001$ \\
\hline \multirow[t]{6}{*}{ Ahomey-Lokpo } & Any & 0 \\
\hline & Distance to water point & 0.78 \\
\hline & Long queue & 4.66 \\
\hline & High water prices & 0.26 \\
\hline & Water break & 0.78 \\
\hline & Other & 0.26 \\
\hline \multirow[t]{6}{*}{ Dékanmey } & Any & 0 \\
\hline & Distance to water point & 1.81 \\
\hline & Long queue & 3.11 \\
\hline & High water prices & 0.26 \\
\hline & Water break & 0.52 \\
\hline & Other & 0.78 \\
\hline \multirow[t]{6}{*}{ Ganvié I } & Any & 0 \\
\hline & Distance to water point & 1.81 \\
\hline & Long queue & 9.84 \\
\hline & High water prices & 1.55 \\
\hline & Water break & 0.52 \\
\hline & Other & 0.26 \\
\hline \multirow[t]{6}{*}{ Ganvié II } & Any & 0.52 \\
\hline & Distance to water point & 3.89 \\
\hline & Long queue & 6.74 \\
\hline & High water prices & 0.52 \\
\hline & Water break & 1.04 \\
\hline & Other & 0.78 \\
\hline \multirow[t]{6}{*}{ Houédo-Aguékon } & Any & 0.26 \\
\hline & Distance to water point & 1.81 \\
\hline & Long queue & 10.88 \\
\hline & High water prices & 0 \\
\hline & Water break & 2.33 \\
\hline & Other & 0.26 \\
\hline
\end{tabular}




\begin{tabular}{lll} 
& Any & 0 \\
\cline { 2 - 3 } & Distance to water point & 2.59 \\
\cline { 2 - 3 } Sô-Ava & Long queue & 2.85 \\
\cline { 2 - 3 } & High water prices & 4.92 \\
\cline { 2 - 3 } & Water break & 3.11 \\
\cline { 2 - 3 } & Other & 0.52 \\
\hline \multirow{2}{*}{ Vêkky } & Any & 6.74 \\
\cline { 2 - 3 } & Distance to water point & 3.11 \\
\cline { 2 - 3 } & Long queue & 9.59 \\
\cline { 2 - 3 } & High water prices & 2.33 \\
\cline { 2 - 3 } & Water break & 6.74 \\
\cline { 2 - 3 } & Other & 1.3 \\
\hline
\end{tabular}

- Washing of drinking-water supply containers

Table 4 showed that approximately $98.96 \%$ of the respondents washed their container before getting water. However, the washing methods used varied from one household to another. The use of water and soap to clean the inside and outside of the containers was the dominant practice in all districts with a frequency between 3.93 and $19.90 \%$. Then comes the washing technique with water and soap from the inside of the container with a rate ranging from 1.31 to $8.38 \%$. The results showed that there was a difference between the different districts in the ways and methods used to wash the container.

Table 4 : Method of washing containers within the boroughs (p-value $=$

$$
\text { 0.014; Chi' }=33.70)
$$

\begin{tabular}{|c|c|c|}
\hline District & Indicator & $\begin{array}{l}\text { Percentage of methods used for } \\
\text { washing the scavenging vessels }\end{array}$ \\
\hline \multicolumn{2}{|c|}{ P-value } & 0.014 \\
\hline \multirow[t]{4}{*}{ Ahomey-Lokpo } & $\begin{array}{c}\text { Water + soap inside and } \\
\text { outside }\end{array}$ & 3.93 \\
\hline & Water + soap inside only & 1.31 \\
\hline & $\begin{array}{l}\text { Simple water inside and } \\
\text { outside }\end{array}$ & 0.26 \\
\hline & Simple water inside only & 1.31 \\
\hline \multirow[t]{4}{*}{ Dékanmey } & $\begin{array}{c}\text { Water + soap inside and } \\
\text { outside }\end{array}$ & 4.71 \\
\hline & Water + soap inside only & 1.31 \\
\hline & $\begin{array}{l}\text { Simple water inside and } \\
\text { outside }\end{array}$ & 0.52 \\
\hline & Simple water inside only & 0 \\
\hline \multirow[t]{4}{*}{ Ganvié I } & $\begin{array}{c}\text { Water }+ \text { soap inside and } \\
\text { outside }\end{array}$ & 8.12 \\
\hline & Water + soap inside only & 4.97 \\
\hline & $\begin{array}{l}\text { Simple water inside and } \\
\text { outside }\end{array}$ & 0.26 \\
\hline & Simple water inside only & 0.52 \\
\hline
\end{tabular}




\begin{tabular}{|c|c|c|}
\hline \multirow[t]{4}{*}{ Ganvié II } & $\begin{array}{c}\text { Water + soap inside and } \\
\text { outside }\end{array}$ & 8.64 \\
\hline & Water + soap inside only & 4.19 \\
\hline & $\begin{array}{c}\text { Simple water inside and } \\
\text { outside }\end{array}$ & 0 \\
\hline & Simple water inside only & 0.79 \\
\hline \multirow[t]{4}{*}{ Houédo-Aguékon } & $\begin{array}{c}\text { Water + soap inside and } \\
\text { outside }\end{array}$ & 10.21 \\
\hline & Water + soap inside only & 3.93 \\
\hline & $\begin{array}{c}\text { Simple water inside and } \\
\text { outside }\end{array}$ & 0.79 \\
\hline & Simple water inside only & 0.52 \\
\hline \multirow[t]{6}{*}{ Sô-Ava } & $\begin{array}{c}\text { Water + soap inside and } \\
\text { outside }\end{array}$ & 10.99 \\
\hline & Water + soap inside only & 2.36 \\
\hline & $\begin{array}{c}\text { Simple water inside and } \\
\text { outside }\end{array}$ & 0.52 \\
\hline & Simple water inside only & 0.26 \\
\hline & $\begin{array}{c}\text { Water + soap inside and } \\
\text { outside }\end{array}$ & 19.9 \\
\hline & Water + soap inside only & 8.9 \\
\hline \multirow[t]{3}{*}{ Vêkky } & $\begin{array}{c}\text { Simple water inside and } \\
\text { outside }\end{array}$ & 0.26 \\
\hline & Simple water inside only & 0.52 \\
\hline & otal & 100 \\
\hline
\end{tabular}

\subsubsection{Phase of drinking water transport}

- The types of containers used for the transport of water

Table 5 showed the type of container used by households during water transport in each district. The use of uncovered containers was the dominant practice in the districts of Ahomey-Lokpo - Dékanmey - Houedo-Aguékon Sô-Ava and Vêkky with rates ranging from 2.85 to $25.39 \%$. With respect to the $27.2 \%$ that covered their containers during transport, it was apparent that $17.1 \%$ of households were found in the districts of Ganvié I and Ganvié II. There was a strongly significant link between the district and the behaviour adopted by the household during the transport of water.

Table 5 : Type of containers used by households when transporting water in each borough

\begin{tabular}{|c|c|c|}
\hline District & Indicator & $\begin{array}{l}\text { Percentage of container types } \\
\text { used in water transport }\end{array}$ \\
\hline \multicolumn{2}{|c|}{ P-value } & $<0.0001$ \\
\hline \multirow[t]{4}{*}{ Ahomey-Lokpo } & Can & 0.52 \\
\hline & Container not covered & 5.18 \\
\hline & Container with lid & 1.04 \\
\hline & Other & 0 \\
\hline \multirow[t]{2}{*}{ Dékanmey } & Can & 0.26 \\
\hline & Container not covered & 5.96 \\
\hline
\end{tabular}




\begin{tabular}{|c|c|c|}
\hline & Container with lid & 0.26 \\
\hline & Other & 0 \\
\hline \multirow[t]{4}{*}{ Ganvié I } & Can & 2.07 \\
\hline & Container not covered & 3.37 \\
\hline & Container with lid & 8.29 \\
\hline & Other & 0.26 \\
\hline \multirow[t]{4}{*}{ Ganvié II } & Can & 1.81 \\
\hline & Container not covered & 2.85 \\
\hline & Container with lid & 8.81 \\
\hline & Other & 0 \\
\hline \multirow[t]{4}{*}{ Houédo-Aguékon } & Can & 0 \\
\hline & Container not covered & 12.18 \\
\hline & Container with lid & 3.37 \\
\hline & Other & 0 \\
\hline \multirow[t]{4}{*}{ Sô-Ava } & Can & 1.04 \\
\hline & Container not covered & 11.4 \\
\hline & Container with lid & 1.55 \\
\hline & Other & 0 \\
\hline \multirow[t]{5}{*}{ Vêkky } & Can & 0 \\
\hline & Container not covered & 25.39 \\
\hline & Container with lid & 3.89 \\
\hline & Other & 0.52 \\
\hline & Total & 100 \\
\hline
\end{tabular}

\subsubsection{Storage of drinking water}

- Types of container used for water storage

Table 6 showed that the plastic seals were more used by respondents to store drinking water with a frequency between 4.66 and $29.53 \%$. The households also used covered jars and other types of containers (cans, uncovered jars, etc.) but in significantly smaller proportions. However, statistical analyzes have shown that the container type was strongly linked to the district.

Table 6 : Type of containers used for water storage in each borough (p-value $<\mathbf{0 . 0 0 0 1}$; $\left.\mathrm{Chi}^{2}=44.15\right)$

\begin{tabular}{ccc}
\hline District & Indicator & $\begin{array}{c}\text { Percentage of types of containers used } \\
\text { for water storage }\end{array}$ \\
\hline P-value & & $<0.0001$ \\
\hline Ahomey-Lokpo & Plastic bucket & 4.66 \\
\cline { 2 - 3 } & Covered jar & 1.81 \\
\cline { 2 - 3 } & Other & 0.26 \\
\hline \multirow{2}{*}{ Dékanmey } & Plastic bucket & 5.44 \\
\cline { 2 - 3 } & Covered jar & 1.04 \\
\cline { 2 - 3 } & Other & 0 \\
\hline Ganvié I & Plastic bucket & 12.18 \\
& Covered jar & 0.52 \\
& Other & 1.3 \\
\cline { 2 - 3 } & &
\end{tabular}




\begin{tabular}{|c|c|c|}
\hline \multirow[t]{3}{*}{ Ganvié II } & Plastic bucket & 12.44 \\
\hline & Covered jar & 0.26 \\
\hline & Other & 0.78 \\
\hline \multirow[t]{3}{*}{ Houédo-Aguékon } & Plastic bucket & 13.21 \\
\hline & Covered jar & 1.81 \\
\hline & Other & 0.52 \\
\hline \multirow[t]{3}{*}{ Sô-Ava } & Plastic bucket & 11.92 \\
\hline & Covered jar & 1.81 \\
\hline & Other & 0.26 \\
\hline \multirow[t]{3}{*}{ Vêkky } & Plastic bucket & 29.53 \\
\hline & Covered jar & 0.26 \\
\hline & Other & 0 \\
\hline Tot & & 100 \\
\hline
\end{tabular}

- Location and washing of the storage container

Only $0.52 \%$ of households installed their storage containers outside their homes. We did not notice a significant difference between the location of the storage container and the district of the household. In terms of hygiene, most households reported washing the storage container but do not always use soapy water. Other investigators have confessed that sometimes simple handshakes with the rest of the water was enough to rinse the container for a new filling. Referring to the work done in Cotonou by Odoulami (2009), the cleaning of water containers is part of households habits. These efforts to maintain containers reflect a certain awareness of households to protect dust receptacles in order to ensure their well-being. Obviously a visual cleanliness aspect does not mean that the containers are free for bacteriological contamination (OXFAM, 2016). As part of this logic, Yadouleton (2015) reports that water can be contaminated by elements present in the sample receptacles, dust, the lid of the storage container. It is for this reason that Nkounkou et al., (2017) recommends that the transport and storage containers should be cleaned daily with a suitable detergent to minimize the risk of water contamination transported or stored.

\subsubsection{Consumption of drinking water}

- Location of the water cup

Table 7 showed that in all districts, most surveyed households used the cup usually placed on the lid with a rate that fluctuates between 6.22 and $27.72 \%$. The number of households that hanged the water draw cup at one point or place it elsewhere was relatively lower than those on the storage container. Our results abound in the same way as those of Yadouleton (2015) which indicate that generally, the water is taken either with a single common bowl to all members of the household or with any bowl. The sampling cups 
are often poorly maintained and when water is taken, the user frequently discharges thousands of microbes in the container if these hands are dirty (Adoko, 2012). All of these practices can be the source of large household water contamination. The analysis of these results showed that there is a highly significant statistical link between the districts and the location of water sampling cup.

Table 7 : Location of water sampling cup in each borough $\left(\mathbf{p}\right.$-value $\left.=\mathbf{0 . 0 1} ; \mathbf{C h i}^{2}=\mathbf{2 6 . 2 0}\right)$

\section{District}

Percentage of drinking cup locations within the household

\begin{tabular}{|c|c|c|}
\hline \multicolumn{2}{|c|}{ P-value } & $<0.01$ \\
\hline \multirow[t]{3}{*}{ Ahomey-Lokpo } & On the storage container & 6.22 \\
\hline & Hanging on a tip & 0 \\
\hline & Elsewhere & 0.52 \\
\hline \multirow[t]{3}{*}{ Dékanmey } & On the storage container & 6.22 \\
\hline & Hanging on a tip & 0.26 \\
\hline & Elsewhere & 0 \\
\hline \multirow[t]{3}{*}{ Ganvié I } & On the storage container & 10.36 \\
\hline & Hanging on a tip & 1.04 \\
\hline & Elsewhere & 2.59 \\
\hline \multirow[t]{3}{*}{ Ganvié II } & On the storage container & 12.18 \\
\hline & Hanging on a tip & 0.78 \\
\hline & Elsewhere & 0.52 \\
\hline \multirow[t]{3}{*}{ Houédo-Aguékon } & On the storage container & 14.51 \\
\hline & Hanging on a tip & 0 \\
\hline & Elsewhere & 1.04 \\
\hline \multirow[t]{3}{*}{ Sô-Ava } & On the storage container & 12.18 \\
\hline & Hanging on a tip & 0 \\
\hline & Elsewhere & 1.81 \\
\hline \multirow[t]{4}{*}{ Vêkky } & On the storage container & 27.72 \\
\hline & Hanging on a tip & 0.78 \\
\hline & Elsewhere & 1.3 \\
\hline & tal & 100 \\
\hline
\end{tabular}

- Treatment of water before use and type of treatment practised by households

Table 8 indicates that the percentage of households that practiced water treatment before home use does not exceed $2.59 \%$. The most wellknown treatment method used by interviewees was chlorination with the use of Aquatabs tablets which is a pharmaceutical product called "sodium Dichloroisocyanurate" for a period of 30 minutes. According to medical requirements, a tablet must be dissolved in 20 liters of water in order to make water suitable for drinking (Chabi-Kenou, 2012). Respondents have less reliance on other techniques such as : decantation (aluminum sulphate or alun) 
and filtration. Statistical tests have shown that there is a very significant relationship between the districts and the treatment of drinking water.

In terms of constraints related to home water treatment, households referred to the reasons for the cost, the availability, the smell, the taste of water after treatment with Aquatabs and the maintenance of the chlorination filter. According to the work of (Odoulami, 2009), the treatment of water by chlorination has a cost which is not affordable by all households due to their poor financial conditions.

Table 8 : Frequency of households treating water before use within each borough (p-value

$=0.008 ; \mathrm{Chi}^{2}=17.28$ )

\begin{tabular}{clc}
\hline District & Indicator & $\begin{array}{c}\text { Percentage of households treating } \\
\text { drinking water before use }\end{array}$ \\
\hline P-value & & 0.008 \\
\hline Ahomey-Lokpo & No & 5.44 \\
\cline { 2 - 3 } & Yes & 1.3 \\
\hline Dékanmey & No & 5.96 \\
\cline { 2 - 3 } & Yes & 0.52 \\
\hline Ganvié I & No & 13.99 \\
\cline { 2 - 3 } & Yes & 0 \\
\hline Ganvié II & No & 12.69 \\
\cline { 2 - 3 } & Yes & 0.78 \\
\hline Houédo-Aguékon & No & 13.99 \\
\cline { 2 - 3 } & Yes & 1.55 \\
\hline & No & 11.4 \\
\hline Sô-Ava & Yes & 2.59 \\
\hline Vêkky & No & 27.98 \\
\cline { 2 - 3 } & Yes & 1.81 \\
\hline Total & & $\mathbf{1 0 0}$ \\
\hline & &
\end{tabular}

\subsection{Households practices in relation to sanitation}

\subsubsection{Place of defecation and cleanliness of latrines}

- Place of defecation

The interpretation of table 9 revealed that defecation in water was a common practice that was observed mainly in the districts of Ganvié I Ganvié II - Houedo-Aguékon and Vêkky, while defecation in open air was most evident in the district of Ahomey-Lokpo - Dékanmey and Sô-Ava. The use of latrines by households was relatively low in all districts of the municipality of Sô-Ava. It is clear from our observations of the latrines cleanliness that very large majorities of the latrines were in a state of unhealthiness. There was a highly significant relationship between the districts and the place of defecation. 
These findings corroborate those obtained by Sachi et al., (2016) who reported that persons surveyed who did not have access to latrines for their needs were more than 5.36 times higher than those with access to latrines.

Table 9 : Location of household defecation within each borough (p-value $<\mathbf{0 . 0 0 0 1} ; \mathbf{C h i}^{2}=$

183.49)

\begin{tabular}{|c|c|c|}
\hline District & Indicator & $\begin{array}{l}\text { Percentage of households } \\
\text { frequented defecation sites }\end{array}$ \\
\hline \multicolumn{2}{|c|}{ P-value } & $<0.0001$ \\
\hline \multirow[t]{3}{*}{ Ahomey-Lokpo } & Latrine & 0.26 \\
\hline & Defecation in water & 0.78 \\
\hline & Open defecation & 5.7 \\
\hline \multirow[t]{3}{*}{ Dékanmey } & Latrine & 2.07 \\
\hline & Defecation in water & 1.3 \\
\hline & Open defecation & 3.11 \\
\hline \multirow[t]{3}{*}{ Ganvié I } & Latrine & 1.04 \\
\hline & Defecation in water & 12.18 \\
\hline & Open defecation & 0.78 \\
\hline \multirow[t]{3}{*}{ Ganvié II } & Latrine & 3.11 \\
\hline & Defecation in water & 9.07 \\
\hline & Open defecation & 1.3 \\
\hline \multirow[t]{3}{*}{ Houédo-Aguékon } & Latrine & 0.26 \\
\hline & Defecation in water & 9.07 \\
\hline & Open defecation & 6.22 \\
\hline \multirow[t]{3}{*}{ Sô-Ava } & Latrine & 2.85 \\
\hline & Defecation in water & 1.81 \\
\hline & Open defecation & 9.33 \\
\hline \multirow[t]{3}{*}{ Vêkky } & Latrine & 1.3 \\
\hline & Defecation in water & 25.91 \\
\hline & Open defecation & 2.59 \\
\hline \multicolumn{2}{|c|}{ Total } & 100 \\
\hline
\end{tabular}

- Mode of disposal of solid and liquid household waste

Table 10 presented the management of household of solid and liquid wastes within the Sô-Ava districts. Most of the households investigated dumped their waste either in nature or in the lake, depending on the place of their home (land or lake). In the districts of Ahomey-Lokpo and Dékanmey, the respondents dropped their waste on the wild dumps, those of HouedoAguékon, Ganvié I and Ganvié II evacuated them in the water. In the Sô-Ava district, the dominant practice was incineration, while at Vêkky the waste disposal rates both on the wild dumps and in the water level were equivalent. Other households preferred to bury or incinerate them. They were used at times for backfilling of access roads to dwellings and puddles. 
As for sewage, the respondents in the districts of Ahomey-Lokpo, Dékanmey and Sô-Ava were used to reject their household solid wastes in nature, contrary to those of Houèdo Aguékon, Ganvié I, Ganvié II, who discharged them in the lake.

Statistical analyzes showed that the mode of disposal of both solid and liquid waste (wastewater) depended strongly on the district of the household.

There was no municipal waste management policy within the Sô-Ava districts, with the consequence of degradation of the environment and the health of the inhabitants of this lacustrine environment. This situation could be explained by poor access to the environment and the lack of garbage collection structure and sewage disposal system.

A recent study by Sachi et al., (2016) on the practice of hygiene by the riverside populations of lake Nokoué reports that households with no dustbins throw their garbage anywhere (in the lake or on the banks). As for those with garbage cans, they bring the garbage to the banks to burn them or to leave them. All those surveyed who were on the lake used to throw their sewage into the lake, while all those who were on the shoreline threw them on the banks.

Table 10 : Mode of household solid waste disposal $\left(\mathbf{p}\right.$-value $\left.<\mathbf{0 . 0 0 0 1} ; \mathbf{C h i}^{\mathbf{2}}=\mathbf{1 1 6 . 2 1}\right)$ and wastewater within each borough $\left(\mathbf{p}-\right.$ value $\left.<\mathbf{0 . 0 0 0 1} ; \mathbf{C h i}^{2}=\mathbf{1 3 6 . 8 0}\right)$

\begin{tabular}{|c|c|c|c|c|}
\hline District & Indicator & $\begin{array}{c}\text { Percentage of } \\
\text { Household Solid } \\
\text { Waste Disposal } \\
\text { Modes }\end{array}$ & Indicator & $\begin{array}{c}\text { Percentage of } \\
\text { wastewater } \\
\text { disposal methods }\end{array}$ \\
\hline & P-value & 0.0001 & & 0.0001 \\
\hline \multirow{4}{*}{$\begin{array}{c}\text { Ahomey- } \\
\text { Lokpo }\end{array}$} & Wild dump & 3.11 & Septic tank & 0 \\
\hline & Lake / river & 0.26 & In the lake / river & 1.04 \\
\hline & Incineration & 2.85 & & \\
\hline & Other & 0.52 & In nature & 5.7 \\
\hline \multirow[t]{4}{*}{ Dékanmey } & Wild dump & 4.92 & Septic tank & 0 \\
\hline & Lake / river & 0.78 & In the lake / river & 0.78 \\
\hline & Incineration & 0.52 & & \\
\hline & Other & 0.26 & In nature & 5.7 \\
\hline \multirow[t]{4}{*}{ Ganvié I } & Wild dump & 0.78 & Septic tank & 0 \\
\hline & Lake / river & 12.44 & In the lake / river & 13.73 \\
\hline & Incineration & 0.52 & & \\
\hline & Other & 0.26 & In nature & 0.26 \\
\hline \multirow[t]{4}{*}{ Ganvié II } & Wild dump & 4.4 & Septic tank & 0.26 \\
\hline & Lake / river & 6.74 & In the lake / river & 11.66 \\
\hline & Incineration & 2.07 & & \\
\hline & Other & 0.26 & In nature & 1.55 \\
\hline \multirow{4}{*}{$\begin{array}{l}\text { Houédo- } \\
\text { Aguékon }\end{array}$} & Wild dump & 4.66 & Septic tank & 0 \\
\hline & Lake / river & 7.77 & & \\
\hline & Incineration & 2.07 & In the lake / river & 8.29 \\
\hline & Other & 1.04 & In nature & 7.25 \\
\hline Sô-Ava & Wild dump & 4.92 & Septic tank & 0 \\
\hline
\end{tabular}




\begin{tabular}{|c|c|c|c|c|}
\hline & Lake / river & 2.59 & \multirow[t]{2}{*}{ In the lake / river } & \multirow[t]{2}{*}{2.85} \\
\hline & Incineration & 5.18 & & \\
\hline & Other & 1.3 & In nature & 11.14 \\
\hline \multirow{5}{*}{ Vêkky } & Wild dump & 10.36 & \multirow[t]{2}{*}{ Septic tank } & \multirow[t]{2}{*}{0.52} \\
\hline & Lake / river & 10.36 & & \\
\hline & Incineration & 5.7 & In the lake / river & 11.14 \\
\hline & Other & 3.37 & In nature & 18.13 \\
\hline & Total & 100 & & 100 \\
\hline
\end{tabular}

\subsection{Households practices in relation to personal hygiene}

\subsubsection{Hand hygiene}

Many authors have shown that soap handwashing is one of the most effective means of preventing diarrhea diseases (Jarvis, 1996 ; Luby et al., 2005).

The present study found that the pratice of handwashing with water and soap or ash is a known practice of the majority of interviewees but is not systematic after the handling of stools and before eating. The rate of interviewees who reported practicing hand washing after handling the stools was between 5.96 and $24.87 \%$. However, handwashing with soap and water is a dominant practice in the boroughs of Ahomey-Love - Ganvié II - Sô-Ava and Vêkky contrary to those of Dékanmey - Ganvié and Houedo-Aguékon where handwashing with water only is the attitude more noticed. Our statistical results showed a strongly significant correlation between the borough and the hand washing mode.

It is worth recalling that the observation of the hand washing device near the latrines has been made and found that only $1 \%$ of the households surveyed had a hand washing device near the latrines against $99 \%$ who did not. In terms of precaution taken before food consumption, the mode is handwashing with simple water with a proportion that varies from 5.44 to $23.58 \%$ within the districts.

The statistical tests showed no association between the districts and the mode of hand washing before food consumption.

Washing hands with soap is one of the hygienic behaviors that WHO considers important to health. According to a study by WHO / UNICEF (2000), nearly $88 \%$ of diarrhea diseases are attributable to poor water quality, inadequate sanitation and defective hygiene. Thus, the adoption of good hygienic practices becomes a permanent quest to be able to prevent certain diseases. 


\subsection{Households practices in relation to personal hygiene}

\subsubsection{Hand hygiene}

Many authors have shown that soap handwashing is one of the most effective means of preventing diarrhea diseases (Jarvis, 1996 ; Luby et al., 2005).

The present study found that the pratice of handwashing with water and soap or ash is a known practice of the majority of interviewees but is not systematic after the handling of stools and before eating. The rate of interviewees who reported practicing hand washing after handling the stools was between 5.96 and $24.87 \%$. However, handwashing with soap and water is a dominant practice in the boroughs of Ahomey-Lokpo - Ganvié II - Sô-Ava and Vêkky contrary to those of Dékanmey - Ganvié and Houedo-Aguékon where handwashing with water only is the attitude more noticed. Our statistical results showed a strongly significant correlation between the borough and the hand washing mode.

It is worth recalling that the observation of the hand washing device near the latrines has been made and found that only $1 \%$ of the households surveyed had a hand washing device near the latrines against $99 \%$ who did not. In terms of precaution taken before food consumption, the mode is handwashing with simple water with a proportion that varies from 5.44 to $23.58 \%$ within the districts.

The statistical tests showed no association between the districts and the mode of hand washing before food consumption.

Washing hands with soap is one of the hygienic behaviors that who considers important to health. According to a study by WHO / UNICEF (2000), nearly $88 \%$ of diarrhea diseases are attributable to poor water quality, inadequate sanitation and defective hygiene. Thus, the adoption of good hygienic practices becomes a permanent quest to be able to prevent certain diseases.

Table 11 : Methods of handwashing before eating (p-value $=\mathbf{0 , 1 3 4} ; \mathbf{K h i}^{\mathbf{2}}=\mathbf{1 7 , 4 3 1}$ ) after handling stool $\left(\mathbf{p}\right.$-value $\left.=\mathbf{0 , 0 0 0} ; \mathbf{K h i}^{\mathbf{2}}=\mathbf{2 7 , 8 1 9}\right)$ within each district

\begin{tabular}{|c|c|c|c|c|}
\hline District & Indicator & $\begin{array}{l}\text { Percentage of } \\
\text { handwashing } \\
\text { modes before } \\
\text { meal } \\
\text { consumption }\end{array}$ & Indicator & $\begin{array}{c}\text { Percentage of } \\
\text { Handwashing } \\
\text { Modes after Stool } \\
\text { Handling }\end{array}$ \\
\hline P-value & & 0.13 & & $\mathbf{0}$ \\
\hline \multirow{3}{*}{$\begin{array}{l}\text { Ahomey- } \\
\text { Lokpo }\end{array}$} & No precautions & 0.26 & \multirow{2}{*}{$\begin{array}{l}\text { Hand washing with } \\
\text { water and soap or ash }\end{array}$} & \multirow[t]{2}{*}{4.72} \\
\hline & $\begin{array}{c}\text { With simple } \\
\text { water }\end{array}$ & 5.44 & & \\
\hline & $\begin{array}{c}\text { Hand washing } \\
\text { with water + soap } \\
\text { / Ash }\end{array}$ & 1.04 & With simple water & 2.65 \\
\hline Dékanmey & No precautions & 0 & & 3.24 \\
\hline
\end{tabular}




\begin{tabular}{|c|c|c|c|c|}
\hline & $\begin{array}{l}\text { With simple } \\
\text { water }\end{array}$ & 4.4 & $\begin{array}{l}\text { Hand washing with } \\
\text { water and soap or ash }\end{array}$ & \\
\hline & $\begin{array}{c}\text { Hand washing } \\
\text { with water + soap } \\
\text { / Ash }\end{array}$ & 2.07 & With simple water & 3.54 \\
\hline \multirow[t]{3}{*}{ Ganvié I } & No precautions & 0.26 & \multirow{2}{*}{$\begin{array}{l}\text { Hand washing with } \\
\text { water and soap or ash }\end{array}$} & \multirow[t]{2}{*}{6.19} \\
\hline & $\begin{array}{l}\text { With simple } \\
\text { water }\end{array}$ & 9.59 & & \\
\hline & $\begin{array}{c}\text { Hand washing } \\
\text { with water + soap } \\
\text { / Ash }\end{array}$ & 4.15 & With simple water & 7.67 \\
\hline \multirow[t]{3}{*}{ Ganvié II } & No precautions & 0 & \multirow{2}{*}{$\begin{array}{l}\text { Hand washing with } \\
\text { water and soap or ash }\end{array}$} & \multirow[t]{2}{*}{8.85} \\
\hline & $\begin{array}{l}\text { With simple } \\
\text { water }\end{array}$ & 9.84 & & \\
\hline & $\begin{array}{c}\text { Hand washing } \\
\text { with water + soap } \\
\text { / Ash }\end{array}$ & 3.63 & With simple water & 4.13 \\
\hline \multirow{3}{*}{$\begin{array}{l}\text { Houédo- } \\
\text { Aguékon }\end{array}$} & No precautions & 0.26 & \multirow{2}{*}{$\begin{array}{l}\text { Hand washing with } \\
\text { water and soap or ash }\end{array}$} & \multirow[t]{2}{*}{7.08} \\
\hline & $\begin{array}{l}\text { With simple } \\
\text { water }\end{array}$ & 12.18 & & \\
\hline & $\begin{array}{c}\text { Hand washing } \\
\text { with water + soap } \\
\text { / Ash }\end{array}$ & 3.11 & With simple water & 7.96 \\
\hline \multirow[t]{3}{*}{ Sô-Ava } & No precautions & 0 & \multirow{2}{*}{$\begin{array}{l}\text { Hand washing with } \\
\text { water and soap or ash }\end{array}$} & \multirow[t]{2}{*}{13.57} \\
\hline & $\begin{array}{l}\text { With simple } \\
\text { water }\end{array}$ & 8.29 & & \\
\hline & $\begin{array}{c}\text { Hand washing } \\
\text { with water + soap } \\
\text { / Ash }\end{array}$ & 5.7 & With simple water & 2.06 \\
\hline \multirow[t]{3}{*}{ Vêkky } & No precautions & 0 & \multirow{2}{*}{$\begin{array}{l}\text { Hand washing with } \\
\text { water and soap or ash }\end{array}$} & \multirow[t]{2}{*}{15.34} \\
\hline & $\begin{array}{l}\text { With simple } \\
\text { water }\end{array}$ & 23.58 & & \\
\hline & $\begin{array}{c}\text { Hand washing } \\
\text { with water + soap } \\
\text { / Ash }\end{array}$ & 6.22 & With simple water & 12.98 \\
\hline Total & & 100 & & 100 \\
\hline
\end{tabular}

\section{Conclusion}

The study evaluated the water, hygiene and sanitation practices used by households in the districts of the municipality of Sô-Ava. It stood out that the majority of interviewees do not put the hygiene rules into practice and do not have access to a good sanitation system. More than half of them are dumping their household waste and sewage into the wild with all the risks that this entails. The lake is therefore constantly polluted by solid waste (household garbage, stool, pet manure) and liquids (sewage, urine) that they produce. This can affect directly or indirectly the quality of the fishery resources and consequently the health of the populations. Thus, a social marketing approach 
should be implemented by the competent authorities in order to: promote the use of disinfectants as aquatabs for drinking water; establish a solid waste collection mechanism for recycling purposes such as compost; decide with the communities the type of latrine suitable to the socio-cultural and morphological context of each district. Finally, the application of the regulations on hygiene and sanitation should be ensured to discourage disobedient people. These actions will be able to significantly improve the living conditions of the populations of the municipality of So-Ava.

\section{Acknowledgements:}

We would like to thank the International Foundation for Science (IFS) for contributing to the achievement of this work.

\section{References}

1. ACF, 2006. Water - Sanitation - Hygiene for populations at risk.

2. Adoko, N.E.I., 2012. Hygiene, sanitation and quality of drinking water in the four urban districts of the municipality of Ouidah (Master's thesis in Environmental Sciences and Sustainable Development). Inter-Faculty Center for Training and Research in Environment for Sustainable Development (CIFRED / UAC), Benin.

3. Ahoyo, T.A., Fatombi, K.J., Boco, M., Aminou, T., Dramane, K.L., 2011. Impact of water quality and sanitation on the health of children in suburban areas in Benin: the case of health zones Savalou-Banté and Dassa-Glazoué. Too much medicine. 71, 281-285.

4. Besancenot, J.P., Handschumacher, P., Ndione, J.A., Mbaye, I., Laaidi, K., 2004. Climate, Water and Health in the West African Sahel. Drought 15, 33-41.

5. Chabi-Kenou, Y.B., 2012. Impact of Floods on Drinking Water Supply in Godomey Borough (Master's thesis in Environmental Sciences and Sustainable Development). Inter-Faculty Center for Training and Research in Environment for Sustainable Development (CIFRED / UAC), Benin.

6. Degbey, C., Makoutodé, M., Fayomi, B., de Brouwer, C., 2010. The quality of drinking water in a professional environment in Godomey in 2009 in Benin West Africa. J Int Health Trav 15-22.

7. Fortin, J., 2008. Social Research: From Problematic to Data Collection published in The ABC of Sampling Methods (Part 2).

8. Hunter, P., MacDonald, A.M., Carter, R.C., 2010. Water Supply and Health. PLoS Med 7, 1-9.

9. INSAE, 2013. Number of population of villages and city districts of Benin (Fourth General Census of Population and Housing (RGPH, 4). National Institute of Statistics and Economic Analysis, Benin. 
10. INSAE, 2006. Demographic Health Survey in Benin. Benin

11. INSAE, 2002. Second General Census of Population and Housing (Synthesis of the results of analysis). National Institute of Statistics and Economic Analysis, Benin.

12. Jarvis, W.R., 1996. Handwashing-the Semmelweis lesson forgotten? 1311-1320.

13. Luby, S.P., Agboatwalla, M., Feikin, D.R., Painter, J., Billhimer, W., Altaf, A., 2005. Effect of handwashing on child health: a randomized controlled trial 225-233.

14. Municipality of Sô-Ava, 2015. Communal Development Plan of SôAva 2016 - 2020. Municipality of Sô-Ava, Benin

15. Municipality of Sô-Ava, 2014. Communal Water Program 2015 2017, Provisional Version. Municipality of Sô-Ava, Benin

16. Nkounkou, L.C., Louzayadio, M.R.F., Ayessou, N., Elouma, N.A.M., Ngakegni-Limbili, A.C., Mar Diop, C.G., Ouamba, J.-M., 2017. Water supply in the city of Brazzaville, Congo. Eur. Sci. J. 21.

17. Odoulami, L., 2009. The problem of drinking water and human health in the city of Cotonou (Republic of Benin) (PhD thesis in Geography and Environmental Management). Faculty of Arts, Arts and Humanities (FLASH / UAC), Benin

18. WHO / UNICEF, 2000. Report on the Assessment of the State of the World's Water Supply and Sanitation (World Water Supply and Sanitation), World Health Organization Publications.

19. WHO / UNICEF, 2014. Progress on Drinking Water and Sanitation (WHO- report).

20. OXFAM, 2016. Protecting the quality of drinking water (Report of the study on water quality in the supply chain and the efficiency of home water treatment methods in the Cascades and Hauts regions -Bassins). Burkina Faso.

21. Sachi, S.P.A., Yaou, I.B., Tchekessi, C.C.K., Banon, S.B.J., Bleoussi, R., Djogbe, A.A., Mensah, G.A., 2016. Assessment of the knowledge and implementation of good hygiene practices by the local populations of Lake Nokoué (South Benin). Int. J. Biol. Chem. Sci. 10, 1823-1831.

22. Yadouleton, M.J., 2015. Environmental sanitation in Cotonou and fight against cholera (University of Abomey-Calavi). Faculty of letter, arts and human science (FLASH / UAC), Bénin. 